\title{
The Role of Sovereign \\ Wealth Funds in Global \\ Financial Intermediation
}

\author{
By \\ Surendranath R. Jory \\ Mark J. Perry \\ Thomas A. Hemphill
}

Sovereign wealth funds (SWFs) have experienced tremendous growth lately. Their combined wealth is currently estimated at $\$ 3$ trillion, and the International Monetary Fund estimates that they will continue to grow to $\$ 10$ trillion by 2012. SWFs' recent investments in the United States and Europe have been the focus of media and government scrutiny, given that a number of SWFs are not transparent, and emanate from authoritarian regimes, which are not political allies of the West. In this article, we provide a comprehensive overview, along with detailed summary statistics on various aspects of SWFs. We also provide recommendations to facilitate SWFs' role in global financial intermediation. @ 2010 Wiley Periodicals, Inc.

\section{Introduction}

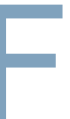

ollowing a series of high-profile international investments in the corporate sector in 2007 and 2008, sovereign wealth funds (SWFs) became the focus of media and government attention among target nations. SWFs are government-owned investment funds, which are set up to invest a country's trade surpluses and/ or excess reserves. Income from SWF investments can be used as a rainy day fund, to help pay for a future liability (for example, public pensions), or by future generations, among others.
SWFs have experienced tremendous growth lately. Their total wealth is estimated at $\$ 3.22$ trillion. ${ }^{1}$ This value is greater than the total assets of hedge funds ( $\$ 2$ trillion) but less than the total official monetary reserves of central banks ( $\$ 6$ trillion). ${ }^{2}$ The International Monetary Fund (IMF) estimates that SWF total assets could grow to $\$ 10$ trillion by 2012 .

While their growth is a welcome source of capital internationally, their lack of disclosure (particularly those from China and the Middle East) had regulators and financial market authorities pondering the political risks that SWFs may pose. While some SWFs are committed to full disclosure 
(for example, Norway and Singapore), many of the world's biggest ones do not report their investment objectives, annual accounts, asset size, and investment portfolios. Therefore, their investment motives are not well understood.

As Philipp M. Hildebrand, member of the governing board of the Swiss National Bank, puts it: "The rise in SWFs has undoubtedly brought a number of benefits. One of these has become particularly evident recently. Against the backdrop of the current market turmoil, SWFs have been a welcome source of capital, strengthening the vulnerable balance sheets of some of the world's largest financial institutions. But they have also given rise to considerable political controversy, as their rapid ascent challenges some long-held assumptions about how the global economy works."

Individually, each SWF is typically endowed with billions of dollars. For example, the Abu Dhabi Investment Authority, a Middle Eastern SWF widely regarded as the world's largest, is estimated to be worth up to $\$ 875$ billion. Therefore, many SWFs have the resources to acquire a sizeable stake and take control of a target company. While their massive investments can boost economic activity, critics (both in and out of government) argue that some SWF investments may be politically rather than commercially motivated. This is due to the fact that they are government-owned; many are not transparent; and many emanate from authoritarian regimes. Russia's stateowned Gazprom cut off gas supplies to Ukraine twice, once in winter 2006 and a second time in winter 2009. Even though it occurred under a different context and did not involve SWFs, the example illustrates the extent of harm that a state-owned corporation may cause.

Given that SWFs represent a relatively new, cash-rich investment group, it is important to study their investment objectives and their roles in the global financial market, and it is this intellectual inquiry that motivates our article. The rest of the article proceeds as follows. In the first section, we define SWFs and look at their various types. We briefly describe the history of SWFs in the next section, and we analyze the multiple benefits of SWF investments in the third section. In the fourth section, we look at the controversies created by SWFs and the ongoing efforts to deal with them. In the fifth section, we present empirical evidence on various aspects of SWFs - for example, their location, size, transparency, funding, objectives, management, portfolio mix, target countries, target industries, and target corporations, among others. We conclude with a summary and recommendations.

\section{Definition and Types of SWFs}

While there is not a precise definition of SWFs, Borgne and Medas provide a comprehensive overview. In their article, the authors define SWFs as vehicles to manage public funds, predominantly engaged in cross-border investments seeking a higher risk-return combination than the one offered by safer investments like government bonds. ${ }^{5}$ SWFs obtain their capital mainly from current account surpluses and excess foreign exchange reserves, and are typically controlled by their governments.

There are two general types of SWFs: commodity and noncommodity. ${ }^{6}$ Commodity SWFs are funded by oil or commodity export revenues, and noncommodity SWFs are funded by transfers from official foreign exchange reserves. According to Butt et al., SWFs belong to a continuum of government-owned investment vehicles that include central banks, sovereign stabilization funds, sovereign saving funds, government investment corporations, and government-owned enterprises. ${ }^{7}$ SWFs include the following variations: sovereign stabilization funds (designed to stabilize revenue), sovereign saving funds (to act as intergenerational funds), and government investment corporations (to invest in riskier assets like corporate bonds, common stocks, and real estate).

Although SWFs belong to their respective governments, an SWF is neither managed like a central bank nor does it form part of a country's foreign exchange reserves. Unlike a central bank, SWFs do not have the day-to-day responsibility for maintaining the stability of the national currency and money supply. And unlike an official foreign exchange reserve, SWFs are not held in foreign currencies. Further, compared to either central banks or an official foreign exchange reserve, SWFs are able to lengthen their investment horizons, assume greater risk, and seek higher returns despite the fact that they are investing state funds.

It is difficult to generalize SWFs as a class. For example, while the majority is owned by national governments, there are also those that are owned by local governments like provinces, emirates, and states (such as in Canada, the United Arab Emirates, and the United States, respectively). Some are managed semi-independently-that is, the government appoints a board to oversee the operations of the SWF (for example, the Australian Government Future Fund) - while others are managed directly by their Ministry of Finance (for example, Indonesia's Pusat Investasi Pemerintah). There are also those that are managed by their central banks (for example, Kazakhstan National Fund and Nigeria-Excess Crude Account). A few SWFs are under the direct control of their head of state (for example, the State Oil Fund of the Republic of Azerbaijan and Venezuela's Fund for Investment of Macroeconomic Stabilization). Some SWFs are set up as a private company under the Companies Act, wholly owned 
by the government (for example, the Government of Singapore Investment Corporation).

Next, all SWFs do not invest in the same way. While some invest primarily in their local economy (for example, Khazanah Nasional BHD in Malaysia), others invest predominantly abroad (for example, the China Investment Corporation). There are SWFs that invest conservatively in safe assets like government bonds, and there are also those that undertake riskier investments through participation in joint ventures and/or private-equity deals and/or buyouts (for example, Abu Dhabi Investment Authority, Abu Dhabi's Mubadala Development Company, and the China Investment Corporation). A few SWFs invest as pension funds in the sense that they are set up to facilitate government savings necessary to meet public pension expenditure (for example, the Government Pension Fund-Global of Norway). While some governments establish only one such fund, others establish a family of those funds (for example, the United Arab Emirates). Therefore, SWFs differ in their objectives, the way they are managed, and their investment approaches.

\section{History of SWFs}

Kuwait founded the first SWF in 1953, the Kuwait Investment Authority (KIA). KIA's objective was to achieve revenue diversification, since Kuwait was overly dependent on revenue from oil exploration and oil sales. Following KIA, there wasn't a major wave of SWF creation until the 1970s, when Singapore, Abu Dhabi, and Canada all created their first SWFs. Norway set up the most transparent—and among the world's largest—SWF in 1990. There was then a second major wave of SWF creation in the 2000s. In 2007, China formed the China Investment Corporation with an initial endowment estimated at $\$ 200$ billion, and Russia announced a pair of new SWFs with a combined wealth estimated at $\$ 150$ billion. Currently, a number of countries have these funds, and a few more have expressed an interest in establishing one. ${ }^{8}$ Most SWFs are located in either oil-producing nations or in economies running trade surpluses.

\section{The Benefits of SWF Investments}

\section{Benefits of SWFs to Recipient Firms}

For a publicly incorporated fund, its cost of capital is usually a weighted average of its costs of debt and equity. However, since SWFs do not borrow money or sell stock to the public, they incur neither a cost of debt nor a cost of equity, which potentially allows SWFs to demand a

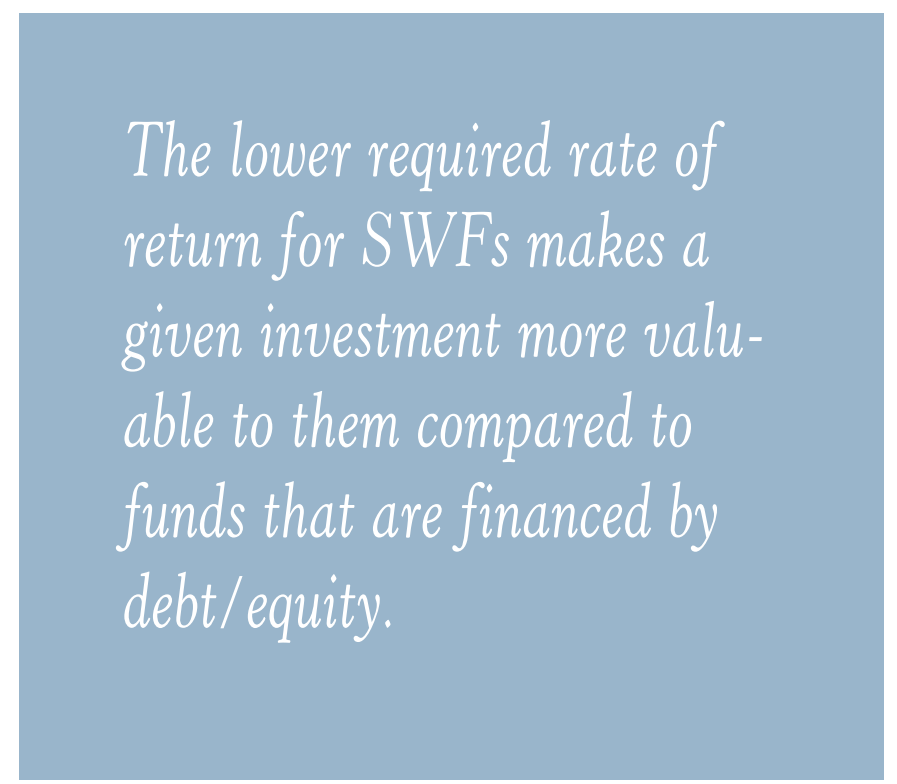

lower rate of return on their investments compared to a private or publicly listed fund.

Likewise, SWFs do not have impending liabilities (like debt) that they are obligated to pay, nor do they have to pay investors who might want to withdraw their capital on short notice. Therefore, they are relatively free to adopt risky strategies over a long-term investment horizon.

Any fund that borrows money faces bankruptcy risk, and as a result, its cost of capital includes a premium for default risk. The higher the risk of default, the higher the default risk premium, and the higher the fund's cost of capital. Because SWFs do not borrow money, plus the fact that they are backed by their government, it should be the case that their cost of capital does not include a default risk premium. With a lower cost of capital, SWFs should be able to supply funds at a lower required rate of return than a leveraged fund. The lower required rate of return for SWFs makes a given investment more valuable to them compared to funds that are financed by debt/ equity.

Stockholders' risk is generally made up of two types: business risk and financial risk. Business risk refers to market- and industry-wide risks that affect a firm's operations irrespective of its capital structure. Financial risk refers to the addition in stockholders' risk, resulting from the firm's use of debt. Therefore, the higher the cost of debt, the greater the increase in stockholder risk, ceteris paribus. Since the cost of sovereign funds can be lower than the 
cost of debt from nongovernment sources, the use of sovereign funds would increase the target's stockholder risk by a lower amount than does the cost of debt.

The fact that SWFs can accept a lower return on investment than funds that are financed by debt holders and stockholders implies that SWFs are generally more likely to provide financing during a financial crisis than traditional funds with private investors. For example, the financial crisis of 2007-2008 led to an increase in the cost of capital for many U.S. financial firms. Since the required rate of return for SWFs can be lower than the rate demanded by other investors, corporations in need of financing during the crisis turned to SWFs for capital.

In Table 1, we present the major SWF investments in the United States during the financial crisis of 2007-2008. In Panel A of Table 1, except for Advanced Micro Devices and MGM Mirage, all of the targeted firms by SWFs are financial ones directly affected by the subprime mortgage crisis. Therefore, recent experience suggests that SWFs can help in mitigating the adverse effects of a liquidity or credit crisis. In fact, SWFs invested nearly $\$ 40$ billion in U.S. financial institutions in 2007 alone during the beginning stages of the subprime crisis. ${ }^{9}$ However, as bank stocks tumbled in 2008 and the crisis worsened, SWFs significantly reduced their investments in U.S. financial institutions.

On a larger scale, SWFs facilitate the global allocation of credit and capital from countries with excess capital to firms that need capital. And not only do SWFs improve access to capital for corporations, but they can also make it available at a lower rate, as explained earlier. This, in turn, potentially increases the value of the investment for which the financing is needed. As a result, value is added to the SWF-financed corporation.

Additionally, considering the stake acquired in target companies in Panel B of Table 1, SWFs are also passive investors. SWFs have not been demanding boardroom changes or changes in executive management in the U.S. companies displayed in Table 1-at least not so far-and they have not been withdrawing funds as markets declined further in 2008 and into early 2009. Rose explains how various statutes discourage SWFs from acquiring a controlling investment in U.S. firms. ${ }^{10}$ Kotter and Lel provide evidence that shareholder activism is not common among SWFs. ${ }^{11}$

\section{The Benefits of SWF Investments on Target Company Stock Price}

Examining the initial stock-price impact of 163 announcements of SWF investments in firms from 28 countries, Kotter and Lel, as well as Fotak, Bortolotti, and Megginson, and Chhaochharia and Laeven, find that investors generally react favorably to these announcements. ${ }^{12}$ On average, the stock price of the target firm increases by $2 \%$ (on a risk-adjusted basis during the three-day window surrounding the announcement date). In dollar terms, the market value of the target firm increases by $\$ 327$ million on average (median increase of $\$ 60$ million) in the first two days of the announcement. However, the market reaction is more favorable for more transparent SWFs, such as Norway and Singapore.

\section{Benefits to Investing Governments}

SWFs provide multiple benefits to their home-country governments. First, through their investments, SWFs enable their governments to diversify their income sources. Diversification allows the minimization of risk and does not leave the government completely exposed to the price volatilities in one commodity/asset. Second, SWFs allow governments to profitably invest their excess foreign exchange reserves, trade surpluses, and/or budget surpluses. Third, by investing in their local industries, SWFs help in creating/preserving employment and growth. Fourth, by investing abroad, an SWF can help to improve the reputation of its home government as being business-friendly and playing an important role in global financial intermediation (as is the case with Dubai and Abu Dhabi). Fifth, by investing abroad, an SWF allows its government the opportunity to access new skills, knowledge, and technology to support the development of its domestic industries and sectors. For example, Dubai's stock exchange is now using a new trading system developed by Nasdaq following SWF investments by its government in Nasdaq and the London Stock Exchange.

\section{When Are SWF Investments Controversial?}

Except for Norway and Singapore, the world's largest SWFs disclose too little information relative to their size. There is ample evidence that a lack of disclosure in these cases generates a lot of political concern. ${ }^{13}$ For example, much of the political furor in the United States has to do with the fact that many cash-rich SWFs are based in countries or areas that are not political allies (for example, Russia, the Middle East, and China).

Among the concerns levied against SWFs are:

1. Their lack of disclosure, especially with regard to their size and objectives;

2. The potential threat of a rival nation employing SWF capital to acquire strategic assets and use them as a potential "weapon" against the recipient country; 
TABLE 1 Sovereign Wealth Funds' Investments in the United States

Panel A: Investments in Publicly Listed Firms

\begin{tabular}{|l|l|l|l|l|l|}
\hline Date & Target & Target's Business & Target Exchange & Acquirer & Origin \\
\hline 25-Jul-07 & Fortress Inv. Group LLC & Asset Management & NYSE & Qatar Investment Authority & Qatar \\
\hline 22-Aug-07 & MGM Mirage & Resorts \& Casinos & NYSE & Dubai World & UAE \\
\hline 20-Sep-07 & Nasdaq Stock Market Inc. & Security \& Commodity Exch & Nasdaq & Borse Dubai \\
\hline 23-Oct-07 & Bear Stearns Cos. Inc. & Security Brokers \& Dealers & NYSE & CITIC Securities Co. Ltd & China \\
\hline 16-Nov-07 & Advanced Micro Devices Inc. & Semiconductors & NYSE & Mubadala Development Co. & UAE \\
\hline 26-Nov-07 & Citigroup Inc. & Money Center Banks & NYSE & Abu Dhabi Inv. Authority & UAE \\
\hline 19-Dec-07 & Morgan Stanley & Security Brokers \& Dealers & NYSE & China Investment Corp. & China \\
\hline 24-Dec-07 & Merrill Lynch \& Co. Inc. & Security Brokers \& Dealers & NYSE & Temasek Holdings (Pte) Ltd & Singapore \\
\hline 15-Jan-08 & Merrill Lynch \& Co. Inc. & Security Brokers \& Dealers & NYSE & Kuwait Investment Authority & Kuwait \\
\hline 15-Jan-08 & Merrill Lynch \& Co. Inc. & Security Brokers \& Dealers & NYSE & Korea Investment Corporation & South Korea \\
\hline 15-Jan-08 & Citigroup Inc. & Money Center Banks & NYSE & Kuwait Investment Authority & Kuwait \\
\hline 15-Jan-08 & Citigroup Inc. & Money Center Banks & NYSE & Government Inv. Corp. & Singapore \\
\hline
\end{tabular}

Panel B: Investments in Initial Public Offerings

\begin{tabular}{|l|l|l|l|l|l|}
\hline Date & Target & Target Industry & Target Exchange & Acquirer \\
\hline 22-Jun-07 & Blackstone Group LLC & Asset Management & NYSE & China State Investment Corp. & China \\
\hline 29-Oct-07 & Och-Ziff Capital Mgmt Grp LLC & Asset Management & NYSE & Dubai International Capital & UAE \\
\hline 7-Apr-08 & Visa Inc. & Business Services & NYSE & Kuwait Investment Authority & Kuwait \\
\hline
\end{tabular}

Panel C: Investments in Publicly Listed Firms

\begin{tabular}{|c|c|c|c|c|c|c|}
\hline Date & Target & Acquirer & Transparency & Amount (\$Mil.) & Transaction/Security & Stake (\%) \\
\hline 25-Jul-07 & $\begin{array}{l}\text { Fortress Inv Group } \\
\text { LLC }\end{array}$ & Qatar Investment Authority & 1 & Undisclosed & Privately negotiated & Minority \\
\hline 22-Aug-07 & MGM Mirage & Dubai World & 5 & 5,200 & $\begin{array}{l}\text { Seasoned Equity Offering } \\
\text { and Public Tender }\end{array}$ & 9.50 \\
\hline 20-Sep-07 & $\begin{array}{l}\text { Nasdaq Stock Market } \\
\text { Inc. }\end{array}$ & Borse Dubai & 5 & Cross Invest & Cross Invest & 19.99 \\
\hline 16-Nov-07 & $\begin{array}{l}\text { Advanced Micro } \\
\text { Devices Inc. }\end{array}$ & Mubadala Development Co. & 3 & 608 & Secondary Equity Offering & 8.00 \\
\hline 26-Nov-07 & Citigroup Inc. & Abu Dhabi Inv. Authority & 3 & 7,500 & Convertible Preferred & 4.90 \\
\hline 19-Dec-07 & Morgan Stanley & China Investment Corp. & 2 & 5,000 & Convertible Preferred & 9.90 \\
\hline 24-Dec-07 & Merrill Lynch \& Co. Inc. & Temasek Holdings (Pte) Ltd & 7 & 4,400 & $\begin{array}{l}\text { Newly Issued Common Stock } \\
\text { in a Private Placement }\end{array}$ & 9.40 \\
\hline 15-Jan-08 & Citigroup Inc. & Kuwait Investment Authority & 6 & 3,000 & Convertible Preferred & 1.60 \\
\hline 15-Jan-08 & Citigroup Inc. & Government Inv. Corp. & 6 & 6,880 & Convertible Preferred & 3.70 \\
\hline
\end{tabular}

Panel D: Investments in Initial Public Offerings

\begin{tabular}{|l|l|l|l|r|l|l|}
\hline Date & Target & Acquirer & Transparency & Amount (\$Mil.) & Transaction/Security & Stake (\%) \\
\hline 22-Jun-07 & Blackstone Group LLC & China State Investment Corp. & 2 & 3,000 & Initial Public Offering & 9.70 \\
\hline 29-Oct-07 & $\begin{array}{l}\text { Och-Ziff Capital Mgmt } \\
\text { Grp LLC }\end{array}$ & Dubai International Capital & 5 & 1,250 & Initial Public Offering & 9.90 \\
\hline 7-Apr-08 & Visa Inc. & Kuwait Investment Authority & 6 & 800 & Initial Public Offering & 4.00 \\
\hline
\end{tabular}


3. The nontraditional investment approach of some (for example, many SWFs from China and the Middle East "bailed out" major U.S. financial firms in the subprime mortgage crisis of 2007-2008 when other investors did not; see Table 1. Many investors feared that the losses due to the credit crisis would persist and they needed more time to determine the full extent of the crisis before they committed more funds.); and

4. The risk that a foreign government will use an SWF to acquire proprietary knowledge, patented technology, or trade secrets. ${ }^{14}$

The weak legal environment and high level of corruption in many countries where SWFs originate complicate the issues even further. ${ }^{15}$

Senator Richard G. Lugar, the ranking Republican on the U.S. Senate Foreign Relations Committee, summarized the political concerns about SWFs this way: "The expansion of sovereign wealth funds is not an inherently negative development. They have infused helpful liquidity into international financial markets and, in some cases, promoted beneficial local development. Yet sovereign wealth funds are not ordinary investors. Their ties to foreign governments create the potential that they will be used to apply political pressure, manipulate markets, gain access to sensitive technologies, or undermine economic rivals." ${ }^{\prime 6}$

As a result of the political concerns, some SWF-target countries have passed legislation to contain the potential political risks of SWF investments. For example, the U.S. passed the Foreign Investment and National Security Act (FINSA) in 2007, and France in 2005, Japan and Canada

As a result of the political concerns, some SWF-target countries have passed legislation to contain the potential political risks of SWF investments. in 2007, and Australia and Germany in 2008 took similar measures. ${ }^{17}$ In October 2008, the IMF published a set of Generally Accepted Principles and Practices, known as the Santiago Principles, as best practices for SWFs. ${ }^{18}$ At the same time, member countries of the Organisation for Economic Co-operation and Development (OECD), which collectively attracts major SWF investments, vowed to treat SWFs fairly and not restrict their investments as long as SWFs do not pose a threat to national security. In March 2008, the U.S. Department of Treasury reached a voluntary agreement with Abu Dhabi and Singapore that their SWFs will invest for purely financial reasons when considering opportunities in the United States. ${ }^{19}$

\section{Empirical Evidence on the Functioning of SWFs}

\section{Data}

Collecting data on SWFs can be very challenging because many SWFs provide very little public information. We use three primary sources for SWF data. The first one is the Sovereign Wealth Fund Institute, a California-based organization designed to study SWFs and their impact on global economics, politics, financial markets, trade, and public policy. ${ }^{20}$ Next, we collect data on SWF investments from the Zephyr database, which covers investment deals and transactions internationally. Zephyr covers investments of smaller value than either Thomson Financial or Mergerstat. Third, we complement data collected from the SWF Institute and the Zephyr database with news searches using LexisNexis Academic. Our sample includes 52 SWFs from 39 countries. However, because not all SWF information is publicly available, our data do not cover the entire universe of SWFs.

Our data allows us to analyze a number of important issues, including: Do SWFs target developed markets only? Do SWFs prefer to be passive investors that invest in minority stakes only? Do they invest in risky assets only? Do SWFs target potentially sensitive sectors like ports and shipping, aerospace and defense, energy and utilities, transportation, and telecommunications? Do they engage in cross-border investments only? What are their stated investment objectives? Are all SWFs located in major geopolitical powerhouses? How are SWFs managed? What is the mix of their investment portfolios?

\section{Results}

\section{Location, Size, and Transparency of SWFs}

Table 2 lists the SWFs and displays (1) the number of SWFs per country, (2) the mean size of an SWF per 
TABLE 2 Number of Sovereign Wealth Funds Including Their Size and Transparency

\begin{tabular}{|c|c|c|c|c|}
\hline Country & Number of SWFs & $\begin{array}{l}\text { Mean Size } \\
\text { (U.S. \$ bn) }\end{array}$ & Mean Transparency Score & $\begin{array}{l}\text { Average } 2000 \text { to } 2008 \\
\text { Current A/C (U.S.\$ bn) }\end{array}$ \\
\hline Algeria & 1 & 47 & 1 & 18.8 \\
\hline Angola & 1 & N/A & N/A & 4.3 \\
\hline Australia & 1 & 43.8 & 9 & -32.8 \\
\hline Azerbaijan & 1 & 10.2 & 9 & 3.1 \\
\hline Bahrain & 1 & 14 & 6 & 1.3 \\
\hline Botswana & 1 & 6.9 & 3 & 1.0 \\
\hline Brazil & 1 & 5.9 & & -4.3 \\
\hline Brunei Darussalam & 1 & 30 & 1 & 4.7 \\
\hline Canada & 1 & 16.6 & 9 & 16.6 \\
\hline Chile & 1 & 21.3 & 7 & 1.4 \\
\hline China & 4 & 147.65 & 4.25 & 152.2 \\
\hline France & 1 & 28 & $\mathrm{~N} / \mathrm{A}$ & -5.3 \\
\hline Hong Kong SAR & 1 & 173 & 7 & 17.6 \\
\hline India & 1 & $N / A$ & N/A & -6.3 \\
\hline Iran, Islamic Repub & 1 & 12.9 & 1 & 14.8 \\
\hline Ireland & 1 & 22.8 & 10 & -5.2 \\
\hline Japan & 1 & $\mathrm{~N} / \mathrm{A}$ & N/A & 152.2 \\
\hline Kazakhstan & 1 & 38 & $\mathrm{~N} / \mathrm{A}$ & -0.6 \\
\hline Kiribati & 1 & 0.4 & 1 & 0.0 \\
\hline Korea & 1 & 30 & 9 & 8.9 \\
\hline Kuwait & 1 & 264.4 & 6 & 29.3 \\
\hline Libya & 1 & 50 & 2 & 15.0 \\
\hline Malaysia & 2 & 14.25 & 4 & 17.6 \\
\hline Mauritania & 1 & 0.3 & 1 & -0.3 \\
\hline New Zealand & 1 & 9.1 & 10 & -6.4 \\
\hline Nigeria & 1 & 11 & 1 & 4.4 \\
\hline Norway & 1 & 301 & 10 & 44.1 \\
\hline Oman & 1 & 8.2 & 1 & 2.9 \\
\hline Qatar & 1 & 60 & 5 & 14.2 \\
\hline Russia & 1 & 189.7 & 5 & 63.9 \\
\hline Saudi Arabia & 2 & 219.15 & 2.5 & 63.7 \\
\hline Singapore & 2 & 232 & 7 & 22.3 \\
\hline Thailand & 1 & $\mathrm{~N} / \mathrm{A}$ & $N / A$ & 5.0 \\
\hline Timor-Leste, Dem.R & 1 & 3.2 & 6 & 0.3 \\
\hline Trinidad and Tobago & 1 & 2.4 & 5 & 2.6 \\
\hline United Arab Emirate & 5 & 242.05 & 4.25 & 22.4 \\
\hline United States & 4 & 13 & 8.5 & -591.3 \\
\hline Venezuela & 1 & 0.8 & 1 & 16.6 \\
\hline \multirow[t]{2}{*}{ Vietnam } & 1 & 2.1 & 4 & -2.3 \\
\hline & 52 & & & \\
\hline \multicolumn{5}{|c|}{ Data collected from SWF Institute (http://www.swfinstitute.org/). } \\
\hline \multicolumn{5}{|c|}{ We used the Linaburg-Maduell Transparency Index to calculate the mean transparency score. } \\
\hline \multicolumn{5}{|c|}{ The source for current account balances is the IMF's World Economic Outlook. Accessed on March 18, 2009.} \\
\hline
\end{tabular}


country in billions of U.S. dollars, (3) the mean LinaburgMaduell Transparency Index of all SWFs in each country, and (4) the average annual current account balance per country from 2000-2008.

The Linaburg-Maduell Transparency Index is published by the SWF Institute and rates SWFs on ten individual transparency factors that result in a composite transparency index measure that ranges from a minimum score of 1 (least transparent) to a maximum score of 10 (most transparent). The Government Pension FundGlobal of Norway is considered the world's most transparent SWF (index value of 10) and is used as the benchmark for maximum fund transparency, largely because its origin, financing, and objectives are all well documented. Moreover, it is subject to independent audits and releases annual reports that are publicly available, and it regularly publicizes the composition of its investment portfolio and performance. Because of its importance as a model of SWF transparency, we provide a detailed description of Norway's SWF in Appendix A. Temasek of Singapore is also perceived as a transparent SWF and, just like the Government Pension Fund-Global of Norway, is in many ways considered a model of transparency for other SWFs. Temasek publishes annual reports and makes the details of its investment portfolio and performance publicly available.

The UAE owns the world's largest SWFs, both in number and size, and its total SWF assets exceed $\$ 1$ trillion. The country with the second-largest SWFs is China, followed by Singapore, Saudi Arabia, Norway, and Russia. The average annual current account balance from 2000-2008 for each of the six countries is positive and among the highest in the world.

The mean Linaburg-Maduell Transparency Index for both UAE and Chinese SWFs is 4.25 (on a scale of 1 to 10). The mean transparency ratings for SWFs in Singapore, Saudi Arabia, Norway, Kuwait, and Russia are 7, 2.5, 10,6 , and 5, respectively. Since the SWF Institute recommends a minimum index value of 8 in order to be seen as adequately transparent, most of the world's largest SWFs are not very transparent, except for Norway.

Our summary statistics for SWFs are consistent with those of Lyons. ${ }^{21}$ Lyons's list of the world's largest SWFs includes Abu Dhabi ( $\$ 875$ billion), China ( $\$ 200$ billion), Kuwait ( $\$ 265$ billion), Norway ( $\$ 400$ billion), Russia ( $\$ 165$ billion), and Singapore (Government of Singapore Investment Corporation and Temasek Holdings, totaling $\$ 490$ billion). Cohen adds Saudi Arabia (estimated at $\$ 365$ bil-

\section{FIGURE 1 Sources of Funding for SWFs}

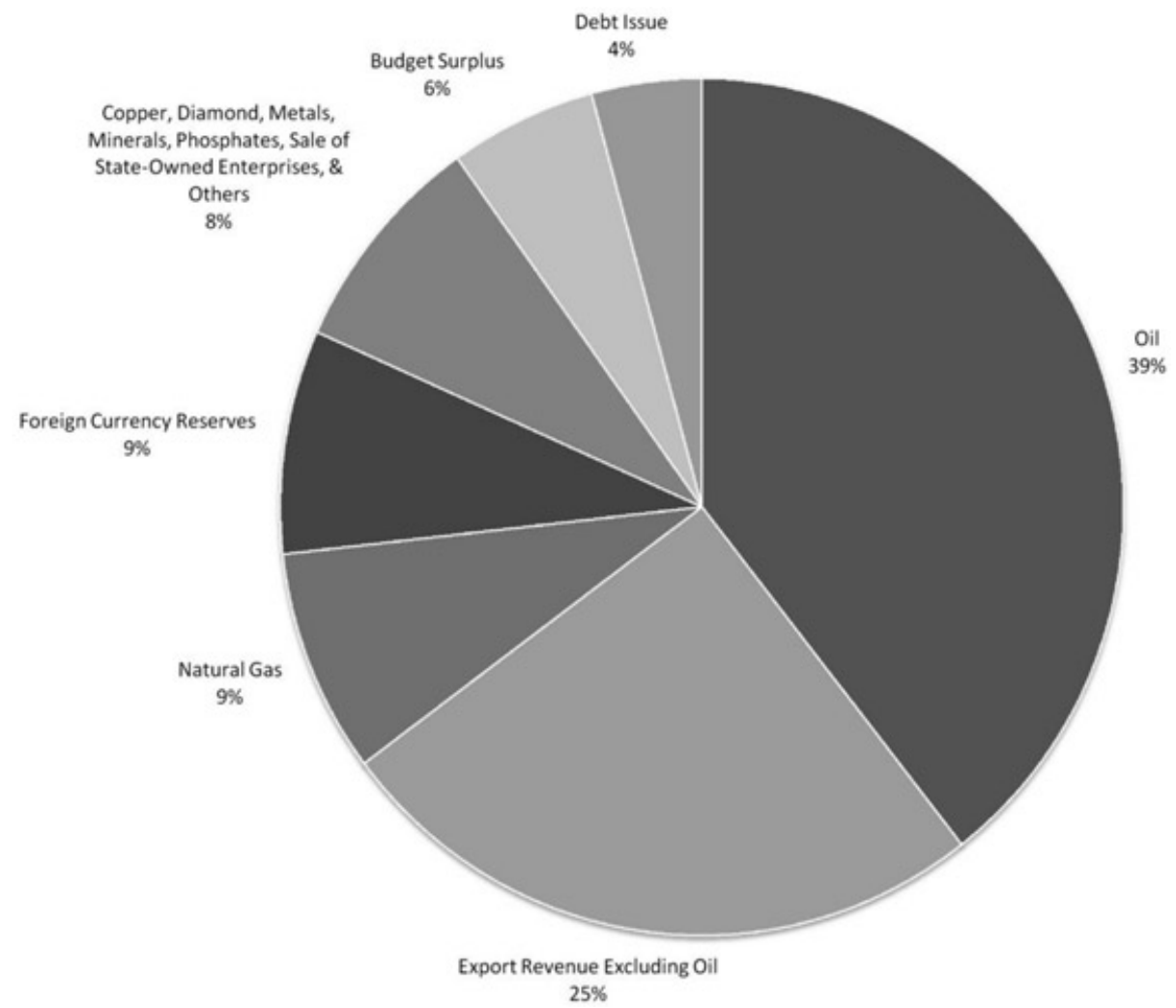


lion) to this list, along with Hong Kong (estimated at \$175 billion), Algeria, Dubai, Libya, and Qatar (each in the range of \$50-100 million). According to Cohen, these 12 countries account for well over $80 \%$ of total SWF assets. ${ }^{22}$

\section{Sources of Funding for SWFs}

Figure 1 presents the sources of funding for SWFs and shows that revenue from oil is the most common source, accounting for $39 \%$ of the total. As shown in Table 2, most of the world's largest SWFs are located in oil-producing nations like the UAE, Saudi Arabia, Norway, Kuwait, Russia, and Qatar, which is consistent with oil being the most important source of funding for SWFs. Revenue from noncommodity exports is the second most significant source of funding for SWFs, especially in countries like China and Singapore.

While many SWFs are funded with export revenue and revenue from the exploration of a natural resource, some SWFs use nontraditional funding sources. For example, the China Investment Corporation is partly financed by issues of government-backed bonds, and the National Security Fund of China is partly financed with revenues from the sale of state-owned assets.

\section{Investment Objectives of SWFs}

We collected data on the investment objectives of SWFs and present the results in Figure 2. We observe that the most common objective is to achieve revenue diversification (34\% of the total). Under the category of revenue diversification, we include all SWFs with one of the following as a stated objective: (1) to curtail reliance on energy exports; (2) to cushion the budget from oil price shocks; (3) to act as a stabilizer/rainy day fund; (4) to achieve revenue diversification; (5) to diversify the government's asset exposure; and (6) to reduce the country's reliance on a single nonrenewable resource. Achieving attractive/high financial returns is the second most cited SWF objective $(13.1 \%$ of total). The third most cited SWF objective is to invest for future generations $(12.9 \%$ of total), since SWFs are seen as a very attractive strategy to save a country's current excess wealth for the benefit of future generations. This strategy works especially well for countries that are presently heavily reliant on revenue from the exploration and trade of a nonrenewable natural resource like oil. Another objective mentioned by a number of SWFs is to address an expected future government pension liability shortfall (e.g., the Government Pension Fund-Global of Norway).

\section{FIGURE 2 SWFs' Objectives}

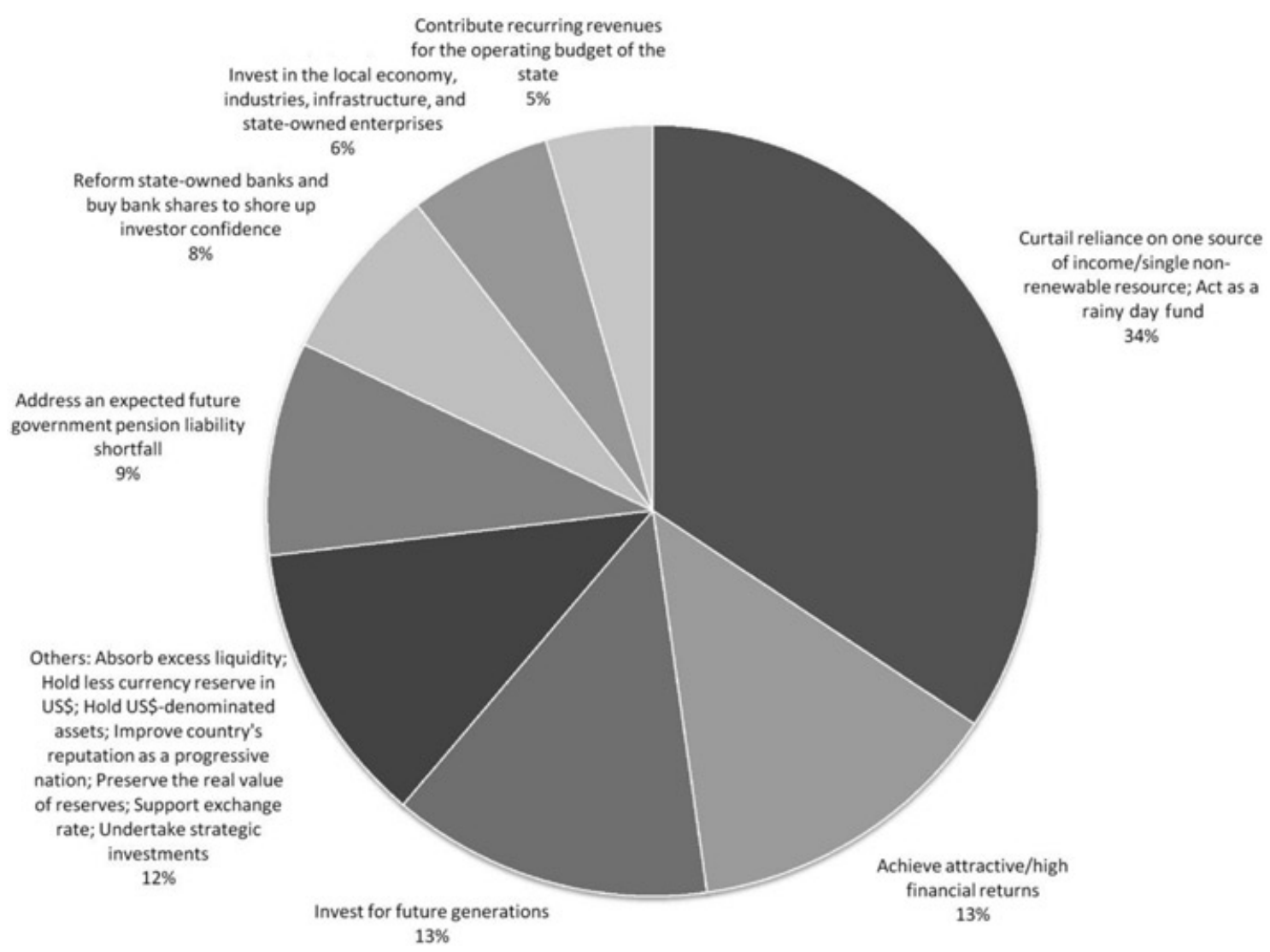


A number of SWFs were established recently. For example, $25 \%$ of the SWFs listed in Table 2 (13 SWFs out of 52 total) were established in 2007 and 2008. That period also coincided with the financial crisis that adversely affected financial markets globally. We observe that a few of the recently created SWFs state that the reform of their domestic state-owned banks and the purchase of domestic banks' shares to shore up investor confidence is an important objective. There are also SWFs that invest in other local sectors apart from the financial sector.

\section{Management of SWFs}

Figure 3 displays data on the management structure of SWFs. Most SWFs fall under the direct control of their Ministry of Finance (23\% of the total). Under this arrangement, SWF management is essentially bureaucratic, with state employees operating the fund on a daily basis, supplemented by a committee of government appointees (usually high-level state officials and outside specialists) that reviews the fund's performance and advises the fund on investment strategies. It would be interesting to compare the skills, experience, remuneration, and performance of these SWF managers with those of fund managers in the private sector. Kotter and Lel find that the proportion of private industry directors on an SWF's board positively affects the market value of the firms receiving investments from that SWF. ${ }^{23}$

We separately categorize SWFs that are set up as investment companies but are still overseen and controlled by their governments. The extent of government interference is lower in this set-up compared to the first. This set-up is the second most common form of SWF (22\% of the total). In third place, we have SWFs that are managed by their central banks ( $16 \%$ of the total). The fourth most common management structure is for local governments to administer SWFs (10\% of the total). In fifth place (6\% of the total), the head of the state personally selects members of the SWF supervisory board.

\section{FIGURE 3 How Are SWFs Managed}

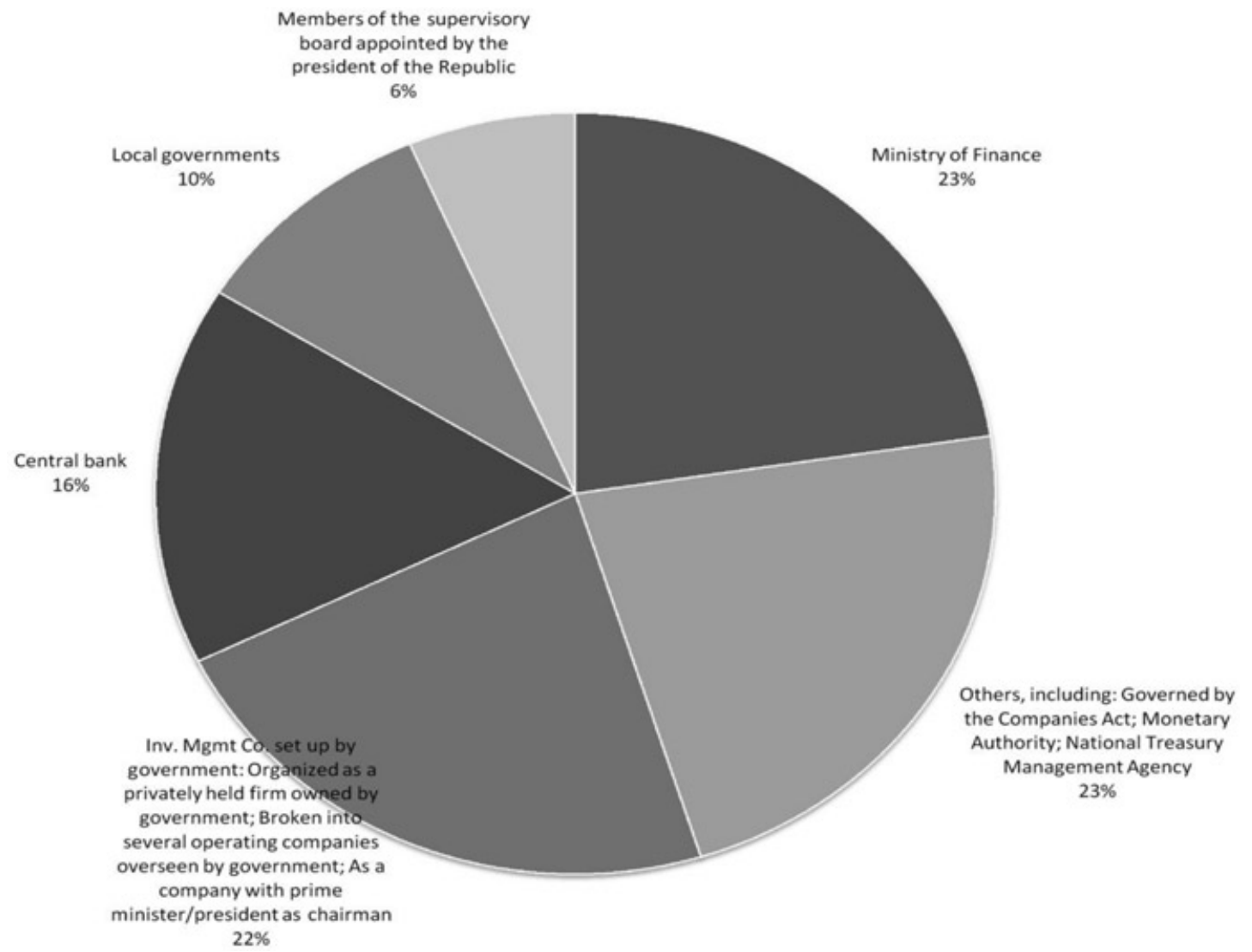




\section{Asset Allocation of SWFs}

In Figure 4, we present data on the asset allocation of SWFs. Fixed-income securities are the most preferred investment securities $(37.5 \%$ of the total), followed by investments in the common stock of listed corporations $(21.25 \%$ of the total). The attractive feature of fixed-income securities is that they provide income certainty as long as the borrowing entity is not in financial distress. The expected returns on listed corporations' common stocks are higher but riskier. The third most common investment asset held by SWFs is real estate ( $11.25 \%$ of the total). Real estate assets typically preserve value and offer considerable potential for capital appreciation over time. The 2009 Preqin Sovereign Wealth Fund Review, published by Research and Markets, finds equity to be the most preferred asset class for SWFs, followed by (in decreasing order of importance) fixed income, real estate, infrastructure, private equity, and hedge funds. ${ }^{24}$ According to the Monitor Group, sovereign wealth funds are estimated to have as much as $\$ 3$ trillion in assets, and much of that money is invested in bonds. ${ }^{25}$

\section{Countries in Which SWFs Invest}

Data on recipient countries of SWF investments are presented in Table 3. The United States is the most favored destination for SWF investments (16.3\% of the total), followed by the United Kingdom (11.2\%) and Singapore $(9 \%)$. Other notable destinations for SWF investments include the UAE (8.7\%), Malaysia (6.9\%), and China (5\%). Our data suggest that SWFs do not exclusively target the OECD markets, but they also make significant investments in both domestic and emerging markets as well.

\section{Industries in Which SWFs Invest}

In Figure 5, we present data on the target industries in which SWFs invest. The financial industry is the most common target industry, with almost $35 \%$ of total funds invested in that one sector. This finding supports the large inflow of SWF money into the U.S. financial industry during the crisis in 2007 and 2008. Since 2007, SWFs from China, Dubai, Kuwait, and Singapore have invested almost $\$ 50$ billion in major U.S. financial firms like Citigroup, Merrill Lynch (which has now been acquired by Bank of America), Morgan Stanley, Bear Stearns (which has now been acquired by JPMorgan Chase), Blackstone Group, and Och-Ziff Capital Management Group (see Table 1).

The real estate industry is the second most common target investment sector (almost $7 \%$ of the total).

\section{FIGURE 4 Asset Allocation of Sovereign Wealth Funds}

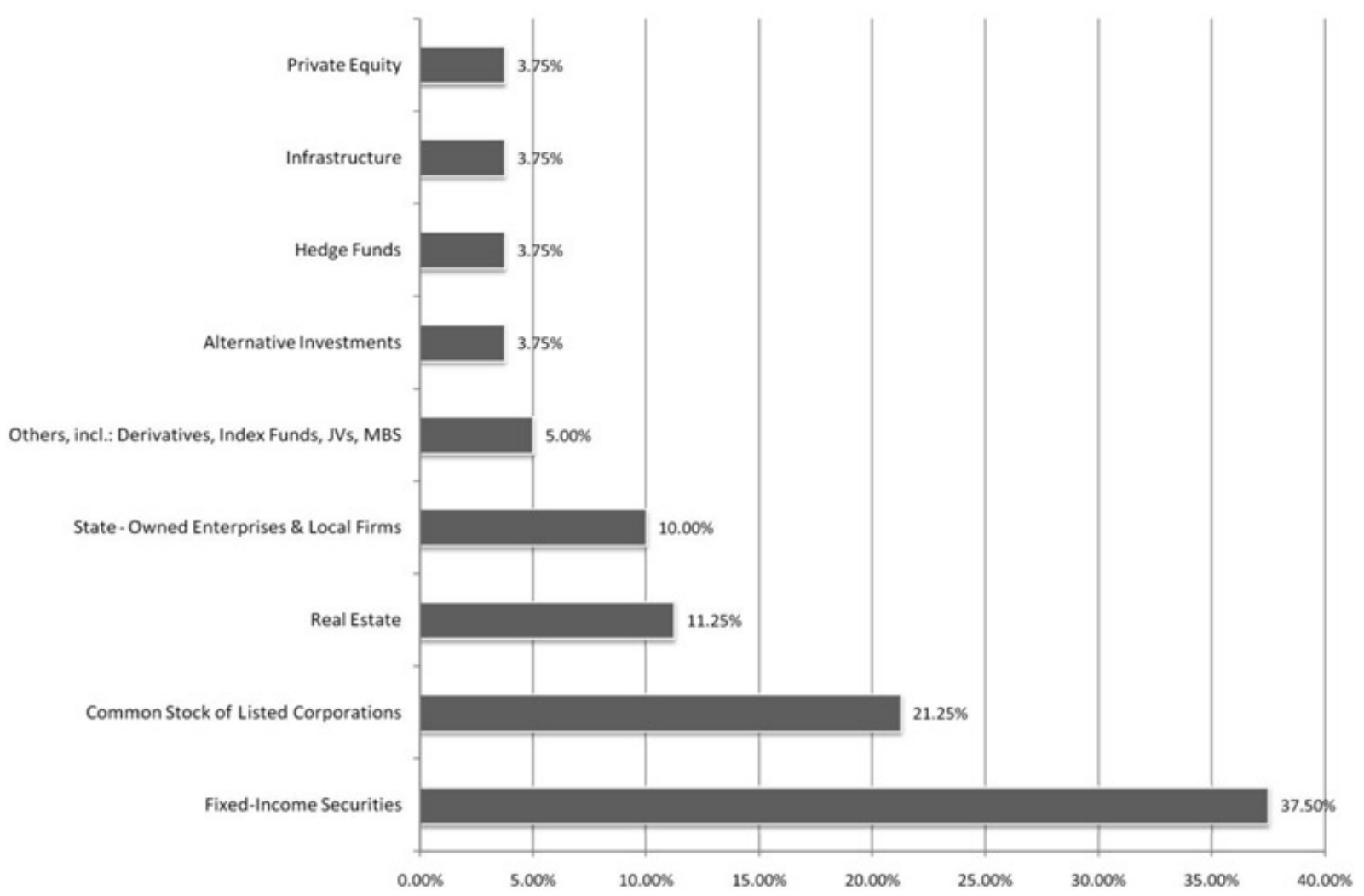


TABLE 3 SWF Target Country for Investment

\begin{tabular}{|c|c|c|}
\hline Target Country & Frequency & Percent \\
\hline Algeria & 3 & $1.09 \%$ \\
\hline Armenia & 1 & $0.36 \%$ \\
\hline Australia & 3 & $1.09 \%$ \\
\hline Austria & 1 & $0.36 \%$ \\
\hline Bahrain & 3 & $1.09 \%$ \\
\hline Bermuda & 2 & $0.72 \%$ \\
\hline Canada & 3 & $1.09 \%$ \\
\hline Cayman Is & 1 & $0.36 \%$ \\
\hline China & 14 & $5.07 \%$ \\
\hline Egypt & 7 & $2.54 \%$ \\
\hline France & 5 & $1.81 \%$ \\
\hline Georgia & 2 & $0.72 \%$ \\
\hline Germany & 7 & $2.54 \%$ \\
\hline Greece & 2 & $0.72 \%$ \\
\hline Guinea & 1 & $0.36 \%$ \\
\hline Hong Kong & 7 & $2.54 \%$ \\
\hline India & 5 & $1.81 \%$ \\
\hline Indonesia & 2 & $0.72 \%$ \\
\hline Italy & 7 & $2.54 \%$ \\
\hline Japan & 4 & $1.45 \%$ \\
\hline Jordan & 5 & $1.81 \%$ \\
\hline Kazakhstan & 1 & $0.36 \%$ \\
\hline Kenya & 1 & $0.36 \%$ \\
\hline Kuwait & 3 & $1.09 \%$ \\
\hline Libya & 3 & $1.09 \%$ \\
\hline Malaysia & 19 & $6.88 \%$ \\
\hline Malta & 1 & $0.36 \%$ \\
\hline Middle East & 1 & $0.36 \%$ \\
\hline Morocco & 1 & $0.36 \%$ \\
\hline Netherlands & 4 & $1.45 \%$ \\
\hline Oman & 3 & $1.09 \%$ \\
\hline Pakistan & 2 & $0.72 \%$ \\
\hline Palestine & 2 & $0.72 \%$ \\
\hline Philippines & 1 & $0.36 \%$ \\
\hline Qatar & 2 & $0.72 \%$ \\
\hline Republic of Benin & 1 & $0.36 \%$ \\
\hline Russia & 1 & $0.36 \%$ \\
\hline Saudi Arabia & 1 & $0.36 \%$ \\
\hline Singapore & 25 & $9.06 \%$ \\
\hline South Korea & 2 & $0.72 \%$ \\
\hline Spain & 1 & $0.36 \%$ \\
\hline Sudan & 1 & $0.36 \%$ \\
\hline Switzerland & 3 & $1.09 \%$ \\
\hline Taiwan & 2 & $0.72 \%$ \\
\hline Thailand & 2 & $0.72 \%$ \\
\hline Tunisia & 4 & $1.45 \%$ \\
\hline United Arab Emirates & 24 & $8.70 \%$ \\
\hline United Kingdom & 31 & $11.23 \%$ \\
\hline United States & 45 & $16.30 \%$ \\
\hline Vietnam & 3 & $1.09 \%$ \\
\hline \multirow[t]{2}{*}{ Yemen } & 1 & $0.36 \%$ \\
\hline & 276 & $100.00 \%$ \\
\hline
\end{tabular}

As explained earlier, we find the real estate sector to be an important asset class in the investment portfolios of SWFs. Alongside real estate, the technology industry also ranks second (almost $7 \%$ of the total) as a target industry for SWFs. Our findings are consistent with those of the Monitor Group in its 2008 SWF Report. ${ }^{26}$ Covering 17 funds, with a total of 785 deals, and some $\$ 250$ billion of investments, it reports that, in terms of the number of deals, $25 \%$ occur in financial services, $18 \%$ in real estate, $15 \%$ in industrials, $10 \%$ in information technology, and $10 \%$ in consumer goods. Figure 5 does not suggest that SWFs only target sensitive sectors and industries.

\section{Types of Companies in Which SWFs Invest}

Figure 6 presents summary statistics on the types of companies targeted by SWFs for investment. Publicly listed corporations are the dominant target company for SWF investment, representing $67 \%$ of the total. SWFs also invest in private corporations (23\%) and state-owned enterprises $(10 \%)$, but to a lesser extent than publicly listed corporations. In the category of publicly listed corporations, we include stock acquisitions on the open market, participation in equity offerings, joint ventures, and buyouts. Also included in this category are acquisitions of convertible preferred stocks and corporate bonds.

\section{Size of SWFs' Equity Stakes}

We collect data on the size of equity ownership positions acquired by SWFs and display the results in Figure 7. The range of equity ownership from 90 to $100 \%$ of the acquired target ranks highest, representing almost $30 \%$ of the total of all equity investments. In this range of equity ownership, we also include buyouts of private corporations and subsidiaries. The 40 to $50 \%$ range is the next most common equity ownership position (almost $20 \%$ of the total deals), which can be explained by the fact that many SWFs are engaged in joint ventures, and we categorize SWFs' participation in joint ventures as $50 \%$ equity. The ownership range below $10 \%$ ranks fifth (13\% of the deals). Therefore, our findings on equity ownership suggest that SWFs are not passive investors only, and take majority ownership positions in more than half of their total investments. Our findings on equity ownership are consistent with those of the Monitor Group. The group found that out of 420 publicly reported equity investments by SWFs since 2000, half involved purchases of majority stakes (i.e., $51 \%$ or higher), but the overwhelming majority of these transactions took place in their domestic and emerging mar- 
FIGURE 5 Industries Targeted by Sovereign Wealth Funds for Investment

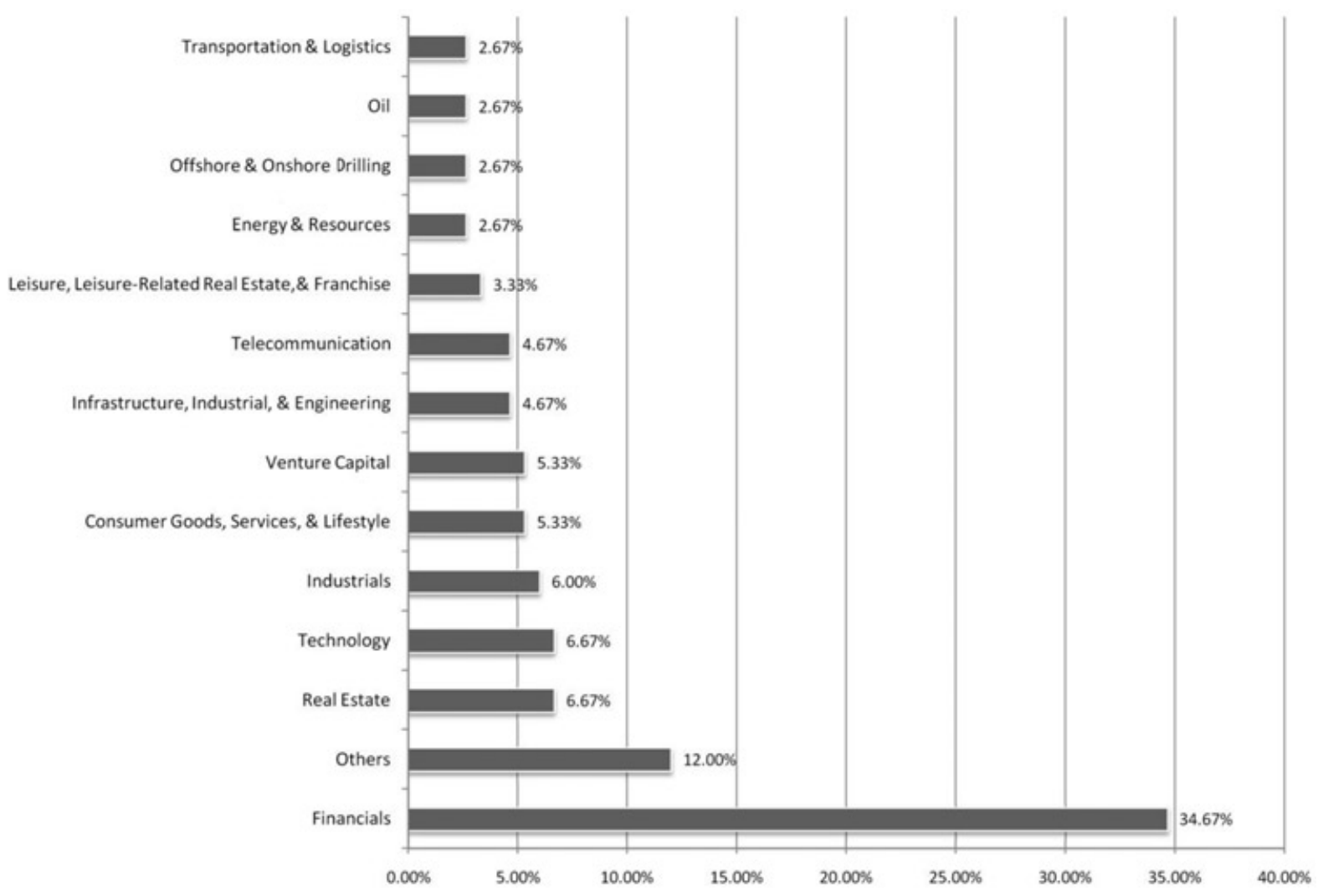

kets. ${ }^{27}$ Thirty-seven percent of the deals involved stakes of between $10 \%$ and $50 \%$.

\section{Summary and Recommendations}

The advent of SWFs was inevitable. The opportunity cost of holding foreign exchange reserves and running trade surpluses in emerging economies have been mounting over time. High oil prices will continue to give oil-exporting countries more financial heft. ${ }^{28}$ Holding excess wealth in a foreign currency and/or risk-free government bonds is not the perfect solution for countries with mounting reserves year after year. First, foreign currency reserves expose countries to foreign exchange risk. Second, the yields on government bonds (for example, U.S. Treasury Bills) have been decreasing over time and are currently very low. By creating SWFs, these countries have been able to invest their excess wealth more profitably. In this concluding section, we propose how the various stakeholders should proceed to accommodate each other.
First, SWFs' governments should improve disclosure. For example, publishing audited annual accounts will help SWFs to be perceived as transparent. Making their investment objectives, portfolio mix, and performance public will improve the transparency of SWFs. In that regard, the Government Pension Fund-Global of Norway, Singapore's Temasek Holdings, and the Government of Singapore Investment Corporation are potential models to follow (see also Appendix A). The more information SWFs make available to the public, the less resistance they will face. Furthermore, homecountry governments should not use SWFs to advance geopolitical goals.

Private equity firms and hedge funds do not disclose information publicly. Therefore, why the call for SWFs to be more transparent? One of the reasons is that private equity firms and hedge funds are not government-owned, do not emanate from authoritarian regimes, and are not engaging in politically controversial investments. Nevertheless, had a private equity firm or hedge fund of the same size as an SWF originat- 
FIGURE 6 Types of Corporations Targeted by SWFs

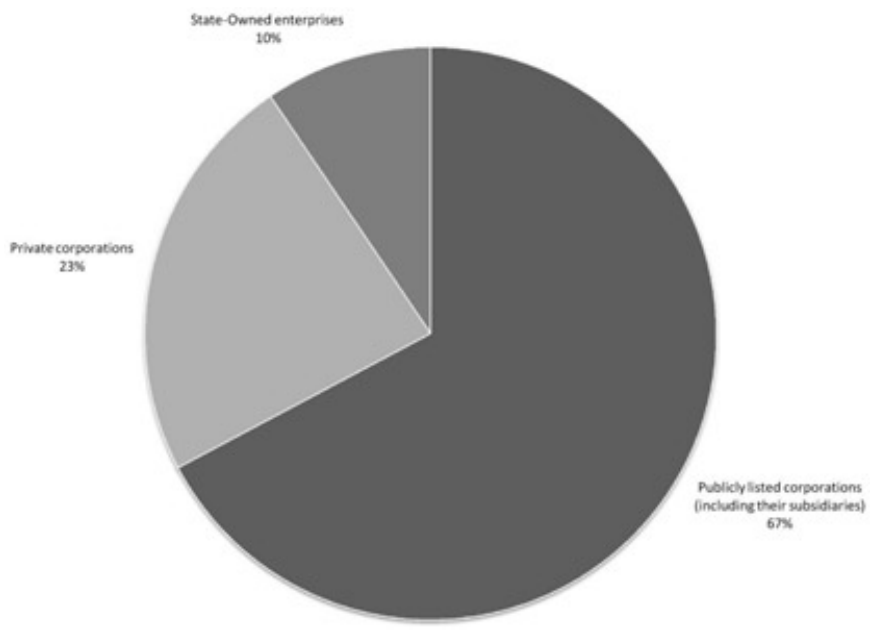

ing from an authoritarian regime been investing in the United States or Western Europe, it could have sparked a similar political furor. While there is no evidence yet of an SWF being used as a political weapon, politi- cal differences will cause some SWF investments to be viewed suspiciously.

Second, while it is important for recipient-country governments to thoroughly scrutinize SWF investments to assess the geopolitical risks that they may pose, it is also important that host-country governments communicate and clarify all the rules and procedures involved to SWF governments. This should be done at a very early stage in the process. Both governments should also assess the noncommercial implications of the investment and the public reactions to them. Hostcountry governments should also make sure that they are seen as assessing all inward investments (SWFs and non-SWFs) in the same way and are not discriminatory.

Last, but not least, while international associations like the IMF, World Bank, OECD, and the European Commission do not have jurisdictional authority over SWFs, they should continue to engage all stakeholders in developing "best operational practices." Even though adherence to the principles is voluntary, the engagement of all parties ensures that they are listening to each other and know what to do to improve their relations and facilitate SWF investments.

FIGURE 7 SWFs' Percentage of Equity Ownership Acquired in Acquisitions of Common Stock (Including IPOs), Joint Ventures, Private Equity Deals, and Buyouts

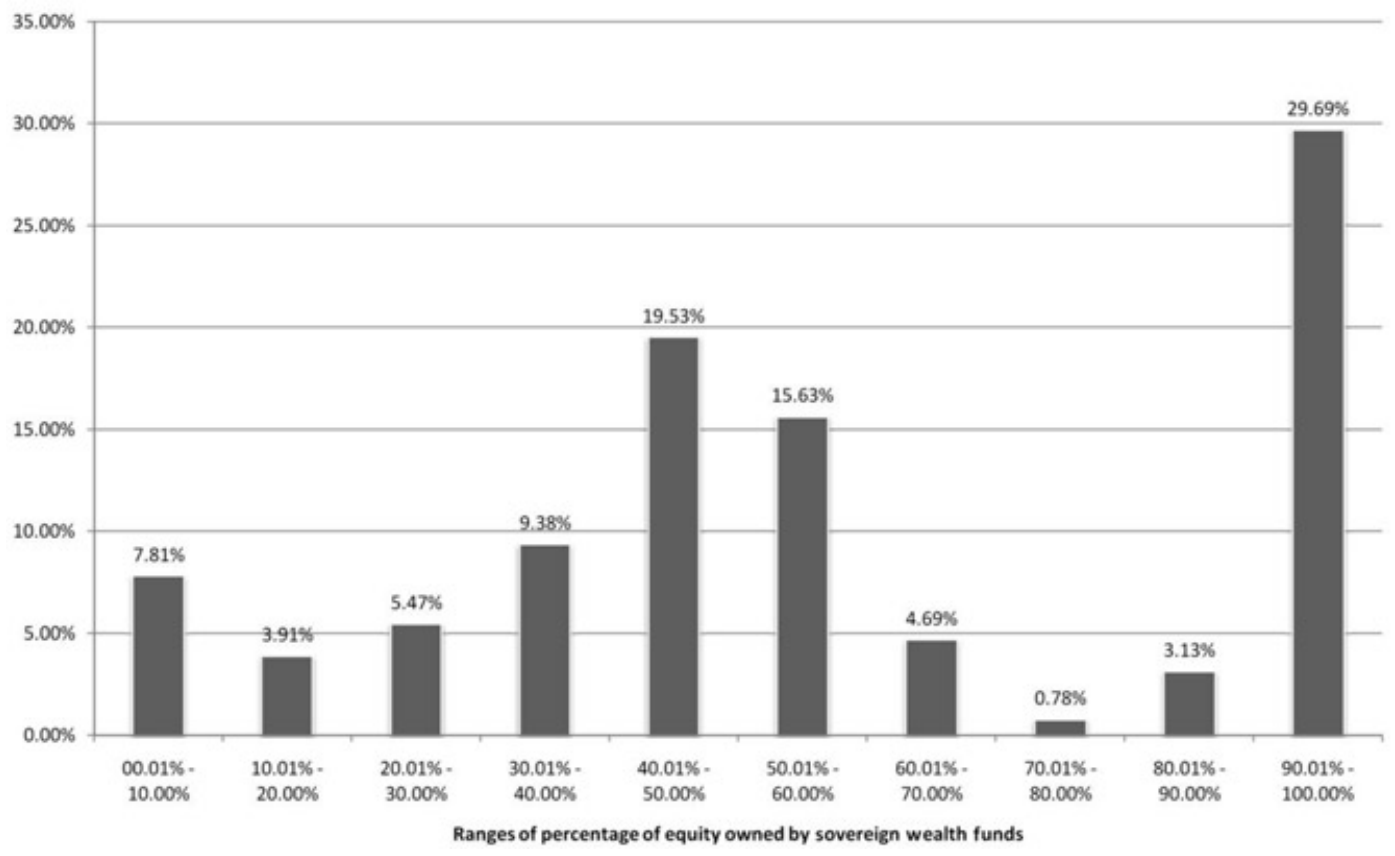


Dr. Surendranath R. Jory is an assistant professor of finance at the University of Michigan-Flint. He holds graduate degrees from the University of Sheffield (MBA in Finance and Accounting) and Florida Atlantic University (PhD in Finance). He is also an affiliate member of the U.K.'s Association of Chartered and Certified Accountants. Dr. Jory has published scholarly articles on various finance topics including corporate bankruptcy, equity offerings, mergers and acquisitions, and government-sponsored funds.

Dr. Mark J. Perry is a professor of finance and economics at the University of Michigan-Flint, and adjunct scholar with the American Enterprise Institute in Washington, D.C. He holds graduate degrees from the University of Minnesota (MBA in finance) and George Mason University (MA and PhD in economics). Dr. Perry's primary academic research is in the area of applied macroeconomics and financial economics, and he has written numerous scholarly articles for economics and finance journals, including the Journal of Finance, the Journal of Monetary Economics, the Journal of International Money and Finance, and the Journal of Applied Econometrics. Since the fall of 2006, Dr. Perry has written daily about economics and finance on his blog, Carpe Diem.

Dr. Thomas A. Hemphill, an assistant professor in the School of Management at the University of Michigan-Flint, received his $\mathrm{PhD}$ in business administration with a primary field in strategic management and public policy and secondary field in technology and innovation policy from The George Washington University. Professor Hemphill's research interests are in the areas of technology and innovation management, corporate governance and business ethics, and international business and political economy. His articles can be found in Technology Analysis \& Strategic Management, Corporate Governance: The International Journal of Business in Society, the Journal of Business Ethics, Thunderbird International Business Review, and Competition \& Change: The Journal of Global Business and Political Economy, among others.

\section{Notes}

1. 2009 Preqin Sovereign Wealth Fund Review prepared by Research and Markets. Retrieved from http://www.researchandmarkets.com/.

2. Caner, M., \& Grennes, T. J. (2008, November 4). Sovereign wealth funds: The Norwegian experience. Retrieved from http://ssrn.com/ abstract $=1295364$.

3. Hildebrand, P. M. (2008, January 21). The challenge of sovereign wealth funds. Retrieved from http://www.voxeu.org.

4. Osborn, A. (2009, January 2). Russia firm cuts gas to Ukraine, but EU hit is cushioned. Wall Street Journal. Retrieved from http://online.wsj. com/article/NA_WSJ_PUB:SB123080339916446769.html.

5. Borgne, E., \& Medas, P. (2007). Sovereign wealth funds in the Pacific island countries: Macro-fiscal linkages. IMF Working Paper. Retrieved from www.imf.org/external/pubs/ft/wp/2007/wp07297.pdf.

6. Kimmitt, R. (2008, January/February). Public footprints in private markets. Foreign Affairs, pp. 119-130.

7. Butt, S., Shivdasani, A., Stendevad, C., \& Wyman, A. (2008). Sovereign wealth funds: A growing global force in corporate finance. Journal of $A p$ plied Corporate Finance, 20, 73-83.

8. See Johnson, S. (2007). The rise of sovereign wealth funds. Finance and Development, 44(3). Retrieved from http://www.imf.org/external/pubs/ft/fandd/2007/09/straight.htm.

9. Åslund, A. (2007, December). The truth about sovereign wealth funds. Foreign Policy. Retrieved from http://www.foreignpolicy.com/ story/cms.php?story_id=4056.

10. Rose, P. (2008). Sovereign wealth funds: Active or passive investors? 118 YALE L.J. POCKET PART 104 (2008). Retrieved from http://thepocketpart.org/2008/11/24/rose.html.

They include (1) the U.S. Treasury Department-proposed rules govern- ing the Committee on Foreign Investment in the United States (CFIUS) process, (2) the regulations under the Bank Holding Company Act (BHC Act), (3) the Change in Bank Control Act (CIBC Act), (4) Section 15 of the Securities Act of 1933, and (5) Section 20 (a) of the Exchange Act of 1934

11. Kotter, J., \& Lel, U. (2008, November 1). Friends or foes? The stock price impact of sovereign wealth fund investments and the price of keeping secrets. FRB International Finance Discussion Paper No. 940. Retrieved from http://ssrn.com/abstract=1292407

12. Fotak, V., Bortolotti, B., \& Megginson, W. L. (2008). The financial impact of sovereign wealth fund investments in listed companies. Working paper. Retrieved from http://finance.sauder.ubc.ca/conferences/ summer2008/files/papers/summer2008_megginson.pdf. Chhaochharia, V., \& Laeven, L. (2008). Sovereign wealth funds: Their investment strategies and performance. Working paper. Retrieved from http:// admin.darden.virginia.edu/emUpload/uploaded2009/sovereign \% 20 wealth\%20funds.pdf.

13. Karon, T., \& Waller, D. (2006, February 20). Who's behind the Dubai company in U.S. harbors? Time. Retrieved from http://www. time.com/time/nation/article/0,8599,1161466,00.html.

14. Johnson, S., La Porta, R., Lopez-de-Silanes, F., \& Shleifer, A. (2000). Tunnelling. American Economic Review, 90, 22-27.

15. Faccio, M., Masulis, R., \& McConnell, J. (2006). Political connections and corporate bailouts. Journal of Finance, 61, 2597-2635.

16. Lugar, R. G. (2008). Opening statement for hearing on sovereign wealth funds, June 11, 2008. Retrieved from http://lugar.senate.gov/ press /record.cfm?id=298990.

17. Cohen, B. J. (2008). Sovereign wealth funds and national security: The great tradeoff. Working Paper, Department of Political Science, University of California Santa Barbara. Retrieved from http://www. polsci.ucsb.edu/faculty/cohen/working/pdfs/SWF_text.pdf. 
18. See http://www.iwg-swf.org/pubs/gapplist.htm.

19. See https://treas.gov/offices/international-affairs/economicexchange-rates/052008_appendix.pdf for details.

20. The Web site address for the Sovereign Wealth Fund Institute is http://www.swfinstitute.org.

21. Lyons, G. (2007). State capitalism: The rise of sovereign wealth funds. London: Standard Chartered Bank.

22. See note 17 .

23. See note 11 .
24. Find report at http://www.preqin.com/itemProduct.aspx?s= \&itemID=1275.

25. Davis, B. (2008, June 6). Sovereign-wealth funds seek control. Wall Street Journal, p. C2.

26. Monitor Group. (2008, June 4). Assessing the risks: The behaviors of sovereign wealth funds in the global economy. Retrieved from http:// www.monitor.com.

27. See also note 25 .

28. See Seib, G. F. (2008, July 8). Pump-price shock blurs national security issue. Wall Street Journal, p. A2.

\section{APPendix A The Government Pension Fund-Global of Norway}

The Government Pension Fund-Global of Norway (GPF) is considered to be a very transparent SWF and a model that other SWFs may follow. In its annual reports, the fund states its objective as "to support government saving to finance pension expenditure and underpin longterm considerations in the use of Norway's petroleum revenue."

GPF falls under the responsibility of the Norwegian Ministry of Finance. However, the latter has delegated management of the fund to Norges Bank Investment Management (NBIM), a unit of the Norwegian central bank (Norges Bank). The fund invests internationally in equities, fixedincome instruments, money market instruments, and derivatives. It has offices in Oslo, London, New York, and Shanghai. It employed 217 people as of December 31, 2008. As well as managing the funds internally, NBIM employs external managers. As of December 31, 2008, NBIM employed 33 external equity managers and nine external fixed-income managers. The market value of GPF is estimated at $\$ 350$ billion.

The Ministry of Finance decides on the fund's investment strategy. It also establishes a benchmark portfolio that the fund has to match. Quarterly reports are prepared and published, as well as annual reports. In 2007, the Norges Bank entered into an agreement with accountancy firm Deloitte AS on financial auditing of GPF. Nonetheless, the ultimate responsibility for the audit rests with the Office of the Auditor General.

As per the fund's benchmark portfolio, equities account for $60 \%$ of the fund's portfolio distributed as follows: Europe $(50 \%)$, America/Africa $(35 \%)$, and Asia/Oceania (15\%). Fixed-income instruments account for $40 \%$ of the portfolio, distributed as follows: European currencies $(60 \%)$, American currencies (35\%), and Asian currencies (5\%). In April 2008, the Government of Norway announced its intention to allow GPF to allocate up to $5 \%$ of its portfolio to real-estate investments. As of December 31, 2008, the fund had equity ownership in 7,900 companies across the globe. A national Council of Ethics reviews the fund's holdings in all these companies based on strict guidelines imposed in 2004. The fund avoids investments in arm manufacturing companies, and those that violate the environment and human rights.

Starting in 2007, the fund has published its voting records in the companies in which it holds equity, together with the basis for the voting decisions. Any investment advice received by the Ministry of Finance from the Norges Bank is rendered public under the Freedom of Information Act. All information related to GPF is available at www.norges-bank.no. 